\title{
Correction to: Male, Failed, Jailed
}

\section{Correction to:}

D. Maguire, Male, Failed, Jailed, Palgrave Studies in Prisons and Penology, https://doi.org/10.1007/978-3-030-61059-3

The original version of this book was inadvertently published with some errors in the text. Those errors have now been corrected. The book has been updated with the changes.

The updated version of the book can be found at https://doi.org/10.1007/ 978-3-030-61059-3

(C) The Author(s) 2021

D. Maguire, Male, Failed, Jailed,

Palgrave Studies in Prisons and Penology, https://doi.org/10.1007/978-3-030-61059-3_10 